\title{
Menyikapi Musibah Alam: Suatu Upaya Meluruskan Kegelisahan Teologi
}

\author{
Rahmani Timorita Yulianti
}

The disasters that happen Indonesia. One of them is tsunami at Aceh, North Sumatra and Nias. When disasters happen, people confuse how to solve them. In this case, people hope to know the factois that cause eartyhquake by ultimate questions. This discourse of course includes theology or philosophical viewpoint. In this connection the question is what God's reason behind of earthquake or disasters that imply many victims. Meanwhlie, Aceh denotes religious field, instead this p[rovince implements islamic Syari'ah. According to the writer of this article that disaster or earthquake happens because of human errors.

Kata kunci: teologi, musibah, Tuhan, manusia

$\mathrm{M}$ usibah demi musibah datang silih berganti. Musibah atau bencana yang terjadi di tengah-tengah kita, akhir-akhir ini, terjadi dalam "bentuk" yang berbeda. Pertama, musibah kecelakaan, yang berupa kecelakaan pesawat terbang komersial, helikopter militer, kereta api, dan sebagainya. Bentuk yang lain, adalah musibah alam, baik itu gempa bumi, banjir bandang dan sebagainya. Kira-kira, manusia sekarang ini mengidentifjkasi "musibah" sebagai segala hal dahsyat, yang terjadi "di luar" kehendak manusia dan menyebabkan kematian dan kesengsaraan banyak manusia."

Dalam pemahaman kebanyakan orang, bencana bersifat linear. Bencana (disaster) dilihat sebagai kejadian tiba-tiba yang tidak bisa diprediksi, di mana ada kerusakan (disruption) dalam skala besar secara fisik dan psikis yang membunuh/ mengancam banyak nyawa manusia. Gempa, banjir bandang, dan badai tropis Siklon sudah dikenal sebagai mesin pembunuh yang bersifat "alamiah" dan "tiba-tiba". Pengertian seperti ini terus direproduksi sehingga orang tidak menganggapnya sebagai suatu kebersalahan. Pada saat terjadinya "musibah" itu, manusia baru merasakan keprihatinan yang mendalam. Tidak tahu apa yang harus dilakukan, tetapi kebanyakan menyerahkan kepada Yang Maha Tunggal. Sayangnya, "penyerahan" kepada Sang Kuasa tersebut ada yang bernuansa $S u^{\prime} u d z-D z a n$ atau Negative Thinking kepada-Nya.

Seperti gempa dan tsunami yang melanda sebagian kawasan Asia dan secara khusus Aceh sebagai yang terparah pada 26 Desember 2004, tercatat pada jaringan seismic dunia diantaranya yang bersimpul di United States Geological Survey (USGS)

'M. Luthfi Thomafi, 2005, "Musibah Alam Dalam Perspektif Teologi Islam" http"//www. pesantrenvirtual. com/artikel. Php? Id =991/ .15: 53: 13 GMT. Accessed, 22 Februari 2005. 
seperti dikemukakan Dani Hilman Natawijaya - peneliti dari Pusat Penelitian Geoteknologi LIPI - merupakan gempa terbesar sepanjang sejarah. ${ }^{2}$ Kemudian disusul gempa dahsyat berkekuatan 8,7 skala richter di Pantai barat Sumatera tepatnya di Nias dan Simeulue pada Senin malam 28 Maret 2005. ${ }^{3}$

Sudah bisa diduga, dalam bencana besar seperti gempa pemboyong tsunami yang menewaskan tak kurang dari 100.000 orang Aceh ini, akan banyak sekali orang yang tidak puas dengan sekadar penjelasan ilmiah. Keterangan para ahli gempa dan tsunami soal lempengan-lempengan bumi yang bergeser setiap tahun, Jantas bergetar, menelan dan lalu memuntahkan air yang sedemikian dahsyat tidak dianggap memadai untuk memuaskan dahaga keingintahuan mereka. Apa keinginan Tuhan dengan semua ini ? Pertanyaan tersebut bisa melintas otomatis dan tidak disengaja, bisa juga merupakan kebutuhan filosofis yang sedikit atau banyak terelaborasi, tapi ia sulit ditekan dan sesungguhnya memang tak bisa ditekan-khususnya bagi pikiranpikiran yang memuji rasionalisme. Maka, melewati kejadian besar seperti ini, chaos biasanya diikuti dengan semacam aktivitas soul searching, yang bisa membawa kita kepada iman yang lebih kuat, atau justru kritis teologis yang mengguncang.

$\because$ Oleh karena itu selalu ada banyak orang yang terobsesi untuk tahu lebih dalam tentang-penyebab terjauh dari semua itu dengan melontarkan pelbagai uttimate questions. Kalau sudah berpikir soal penyebab terjauh, perbincangan tentulah sudah masuk ke ranah filsafat atau teologi. Kemudian muncul pertanyaan: sejauh apa peran Tuhan di dalam "menghajar" sedemikian banyak korban itu? Pada titik inilah spekulasispekulasi teologis berlangsung dengan begitu liarnya. di sebagian masyarakat muslim. Pada satu sisi, mereka mengetahui kejadian semacam itu - dari berbagai literatur kitab suci - sering terjadi pada masa dulu, yang menimpa umat-umat yang membangkang para nabi. Mereka dibinasakan atau dihancurkan karena menentang ajaran Tuhan yang disampaikan nabi.

Namun, pada sisi lain, Aceh adalah kawasan religius, bahkan telah memproklamasikan diri sebagai daerah yang memberlakukan penerapan syariat Islam. Jadi, seharusnya, Aceh mendapat berkat dari karunia Tuhan, tetapi malah ditimpa gempa dan terjangan tsunami yang hanya layak menimpa mereka yang durhaka.

Mengapa masyarakat Aceh yang harus menjadi korban paling parah dari peristiwa dahsyat tersebut? Mengapa bukan kaumkaum yang telah berbuat zalim kepada kemanusiaan dan membangkang perintah Tuhan yang dibinasakan? Ada apa dengan Aceh? Apakah Tuhan keliru menimpakan murkanya? Begitulah kira-kira pertanyaanpertanyaan teologis yang sering terdengar di masyarakat belakang ini. Oleh karena itu penulis merasa penting mengangkat hal ini karena kegelisahan teologis pada masyarakat harus segera diluruskan. Agar Aceh yang menjadi korban gempa dan terjangan tsunami tidak semakin menderita oleh ungkapan-ungkapan. yang spekulatif.

\section{Musibah Alam dan Isu-isu Teologis}

Sebenarnya makna "musibah" dalam kacamata teologi Islam tidaklah sesederhana dari yang selama ini dipahami. Kalau mau menyisakan perhatian kepada pemahaman -

2 Yun, 2004, “Gempa itu Terbesar Sepanjang Sejarah", Dalam Kompas, 27 Desember 2004. Jakarta.

${ }^{3}$ Afp dkk. 2005, “Mengapa Tsunami Tidak. Terjadi". Dalam Jawa Pos, 30 Maret 2005. Surabaya. 
sekelompok umat Islam, maka akan ditahui bahwa ada sebagian umat yang merasa bahwa pemberian penghargaan, kenaikan jabatan, bagi mereka, itu pun sebuah "musibah". Sudah tentu, hal tersebut "musibah" bagi yang bersangkutan. Biasanya, orang yang berpedoman demikian akan semakin tunduk kepada Allah Swt ketika mendapatkan penghargaan. Dari sinilah bisa dipahami bahwa sudah sewajarnya jika Nabi Muharnmad Saw bersabda bahwa manusia yang paling sering mendapatkan musibah \& cobaan berat adalah para nabi, kemudian para wali, dan seterusnya. Karena musibah yang di-"uji-coba"-kan kepada para nabi tersebut tentunya bukan saja berupa fisik, melainkan mental dan keimanan. Dari pemahaman ini, IbnuTaymiyah-seperti dinukil Ibrahim Khalifah dalam salah satu kajian Tafsir-nya-berpendapat bahwa sangatmungkin para nabi itu berkurang imannya bahkan murtad-walaupun pada kenyataannya hal tersebut tidak pernah ada dalam sejarah. ${ }^{4}$ Perkembangan kehidupan materialisme mampu menyingkirkan pemahaman-pemahaman "unik" tentang musibah tadi. Akhimya, manusia sekarang ini pun telah lebih jauh menyederhanakan makna dan "Talsafah" atas pengertian "musibah".

Manusia tidak lagi berpengertian bahwa, sebenarnya, musibah tidak sesederhana "segala bencana yang di luar kehendak manusia". Akibatnya, sepertinya ada dua pilihan, menerima sepenuhnya sebagai sebuah kecelakaan alam murni, atau mengkaitkannya dengan kehendak Sang Kuasa. Pilihan pertama sudah jelas, ia lebih banyak di-"imani" masyarakat Barat. Pilihan kedua adalah pilihan yang hingga kinj masih dipegang umat Islam. Hanya saja, pilihan kedua ini masih berupa pemahaman yang global dan masih banyak umat Islam yang belum dapat memahami penjabaranpenjabaran dari teologi ini.

Pada kenyataannya di masyarakat In- donesia terdapat beberapa spekulasi teologis yang semarak bermunculan pascagempa dan tsunami yang menghentakkan nurani dunia. Pertama, bagi "kiai-kiai Orba" yang punya corong untuk berkhotbah di masjid-masjid itu, bencana sebesar itu tak lain adalah hukuman Tuhan atas kealpaan dan kesombongan kita selama ini. Lebih spesifik, mereka bahkan menyebut bencana tersebut sebagai akibat atau buah darj pertikaian antara pelbagai elemen anak bangsa di Serambi Mekkah yang tidak kunjung usai.

Dengan elaborasi yang cenderung menyederhanakan, mereka menyayangkan TNI dan GAM yang saling bunuh. Sementara itu, rakyat Aceh juga tak kunjung taat terhadap NKRI. Demikian tafsiran teologis yang sepenuhnya spekulatif dan kental aroma pemikiran ala Orba tersebut menggema di sebagian masjid.

Kedua, berbeda dengan logika hukuman tadi, tafsiran kedua justru ber-anggapan bahwa tragedi tersebut justru bersifat ujian, bukan hukuman. Di beberapa tempat, dapat ditemukan selebaran yang menyatakan antara lain, bencana Aceh merupakan "ujian" Tuhan untủk mengukur keteguhan dan konsistensi rakyat Aceh dalam menjalankan syariat Islam. ${ }^{5}$

Selain isu-isu tersebut muncul pula isu pemurtadan, kristenisasi, dan adopsi dihembuskan sebagian pihak yang mungkin sedang meneguk di air keruh, justru pada saat proses evakuasi dan rehabilitasi Aceh. Untuk mencermati diskursus tentang Tuhan dan prasangka tentang keterlibatannya dalam musibah alam di Aceh tersebut

${ }^{4}$ M. Luthfi Thomafi, Loc. Cit.

${ }^{5}$ Nouviantoni, 2005. Tuhan Pasca Tsunami http:/www.kompas.com/kompas-cetak/ 0501/14/opini/1492211.htm/11:29:00 GMT. ACcessed. 17 Januari 2005. 
terdapat kajian-kajian teologis yang beranjak dan bertolak dari keprihatinan yang mendalam akan rumusan 'teologi bencana alam" yang berkembang dan populer di tengah masyarakat dewasa ini. Seperti yang dilakukan oleh jaringan.Islam Liberal (Jii), melangsungkan diskusi soal "Tuhan Pasca-Tsunami" yang bertempat di Freedom Institue, tanggal 11 Januari 2005 lalu.

Baik Goenawan Mohamad maupun Syamsurizal Panggabean yang bertindak sebagai pembicara dalam diskusi itu samasama prihatin akan rumusan teologis yang tidak sungkan-sungkan mengekspos "intervensi" Tuhan yang berlebihan dalam kiamat kecil itu. Kecenderungan seperti itu gampang sekali disimak dari khotbahkhotbah Jumat, pengajian di majelis taklim maupun majelis zikir, atau ceramah keagamaan di sejumlah televisi. ${ }^{6}$

Kesimpulannya telah muncul rumusan teologi tentang bencana alam (tidak murni buatan manusia seperti tragedi Poso dan Maluku) yang pada akhirnya tetap terjebak di dalam dua perangkap teologis yang mengharukan: entah mengambing-hitamkan korban bencana sendiri ataupun menyalahkan Tuhan yang dianggap sebagai pihak yang tak pandang ampun dan tak kenal belas kasihan menghajar hamba-hambaNya. Kedua kecenderungan itu rupanya juga bagian dari pandangan teologi masyarakat kita yang cenderung fatalistik.

Ketika rumusan teologis yang dikemukakan mengasumsi bahwa bencana Aceh dan Nias adalah refleksi dari kemurkaan Tuhan, di situ secara eksplisit sudah terkandung nada-nada yang menyudutkan dan menyalahkan rakyat Aceh yang kini menjadi korban. Sebaliknya, ketika bencana tersebut dianggap sebagai "ujian" Tuhan untuk umat manusia yang Dia cintai, sebagaimana yang dikatakan sejumlah kutipan kitab suci, secara implisit kita juga sedang terlibat dalam proses menyalahkan Tuhan (blaming God). Kedua kecenderungan tersebut tentu bukanlah rumusan teologis yang bisa dianggap elegan dan ideal tentang bencana alam.

Oleh karena itu diperlukan rumusan teologis yang tidak gegabah dan potensial menambah luka dan duka rakyat Aceh sekaligus berpandangan elegan dan fair terhadap Tuhan sendiri. Rumusan teologis demikian yang sekarang sedang dicari dan dikehendaki.

Tetapi persoalannya tidak segampang yang di kira. Sebagaimana dikemukakan Ulil Abshar-Abdalla dalam suatu diskusi, godaan bagi agama (diwakili oleh pemuka agama ataupun juru khotbah tadi) ataupun ilmu pengetahuan untuk menjelaskan sejumlah misteri yang terkandung di dalam dunia ini teramat besar. Oleh karena itu, sejumlah misteri dan absurditas yang terkandung di dalam pelbagai peristiwa di dunia keduanya diterangkan baik oleh agama maupun ilmu penge-tahuan. ${ }^{7}$

Secara psikologis, manusia tidak pernah nyaman menjalankan hidup dengan menyisakan sejumlah misteri karena misteri adalah kegelapan. Sedangkan, kegelapan pada hakikatnya adalah situasi yang cenderung dibenci. Untuk itu, kegelapan tersebut dicoba diterobos dan diterangi, baik dengan penjelasan ilmu pengetahuan maupun penjelasan agama atau teologi.

Tetapi, kenyataannya bahwa penjelasan ilmu pengetahuan dan penjelasan agama memang berbeda. Manusia bisa memahami sebuah misteri secara lebih pasti dan dapat memverifikasinya secara ilmiah dengan perangkat dan metode yang disediakan ilmu pengetahuan. Sebaliknya,

\footnotetext{
${ }^{6}$ Novriantoni, Ibid.

7 Ibid.
} 
penjelasan agama tak jarang justru menjelma menjadi deretan spekulasi yang tiada henti. Selain itu naifnya, manusia tidak pernah kunjung bisa memverifikasi sisi kebenarannya kecuali meyakini saja. Manusia sesungguhnya tidak pernah bisa menanyakan kebenaran "versi Tuhan" akan bencana Aceh, apalagi mendialogkannya secara langsung.

Karenanya, para sosiolog cenderung mengatakan bahwa "kebenaran agama" tidak pernah bisa dibuktikan dan bersifat prapengalaman. Walaupun sedang berspekulasi secara liar, Dia selalu saja diimani sebagai kebenaran yang hakiki, sekalipun belum dibuktikan. Di sinilah problematisnya spekulasi-spekulasi tentang Tuhan dalam tsunami kemarin. ${ }^{8}$

Tidak seorang pun yang bisa membuktikan kalau Tuhan ikut aktif mengintervensi peristiwa tsunami yang kemarin menghantam Aceh. Siapa yang tahu pasti kalau hal tersebut ditujukan untuk memberi "pelajaran" kepada rakyat Aceh yang ironisnya justru taat beragama? Maka selain melakukan proses evakuasi dan rehabilitasi Aceh, manusia juga dipanggil untuk mencari rumusan teologi bencana alam yang lebih mengena. Sementara itu juga tidak terlalu lancang dan sok mengerti soal apa sebenamya yang dimaui Tuhan dari bencana tersebut.

Klaim atau perasaan bahwa manusia tahu tentang apa yang dimaui Tuhan dalam bencana tersebut, sekalipun bersandar pada argumen dan landasan firman-Nya, sesungguhnya merupakan bentuk kesombongan yang tiada tara. ${ }^{9}$

Ketika mengupas bencana gempa bumi dan gelombang tsunami yang menimpa Aceh, para pendakwah risalah Islam merujuk pada ayat-ayat Alquran yang mengisahkan bencana-bencana serupa di masa lampau.
Tentang bencana yang menimpa kaum Saba di negeri Yaman. Bencana kaum Madyan di zaman Nabi Suaib. Bencana kaum Hud, Nuh, bahkan yang menimpa Firaun di Laut Merah. Pendek kata negeri-negeri dan rakyat yang diluluhluntakkan Tuhan karena inkar dan tak bersyukur. Negeri dan rakyat yang tidak beriman dan bertaqwa. Rakyat yang tak lagi menjalankan perintah syari'at Islam yang dibawa para Rasul Allah.

Lalu Allah yang Mahaperkasa dan pemberi siksa dikonstruksikan sebagai kekuatan yang berada di balik seluruh kejadian alam yang dahsyat tersebut. Manusia dengan seluruh alam dan isinya sungguh tak ada artinya. Sangat kecil dan tak berarti apa-apa di hadapan Allah yang Mahaperkasa. Dan bagi umat beriman, memang Allah adalah yang Mahasegalagalanya, tiada tandingan dan bandingan apa pun. Tuhan yang berada di balik gerak-gerik alam dan isinya.

Tapi, tepatkah berbagai bencana di muka bumi, terutama dalam peristiwa musibah Aceh, adalah cermin dari siksa Tuhan sebagaimana ditimpakan kepada para umat terdahulu yang ingkar dan berbuat fasad? Di sinilah kita perlu berhati-hati. Bahwa firman Allah sungguh haq, tak ada yang membantah, kecuali bagi mereka yang tak beriman.

Bahwa Allah Mahasegala-galanya juga haqgal-yakin, tak ada keraguan sedikit pun bagi kaum beriman. Tapi, menjelaskan sebuah peristiwa dengan peristiwa serupa yang berbeda konteks dan keadaannya, bisa mengandung salah tafsir dan salah terapan. Bahkan menghadirkan Tuhan dalam tafsir yang tak tepat. Malah bisa mengandung risiko teologis yang tidak sederhana, yang bisa mengandung kesan tak tepat pula

Ibid.

Ibjo. 
bagi mereka yang awam agama tentang Tuhannya. Seolah Tuhan tak adil.

Nalar logis bisa menggugat. Bagaimana mungkin rakyat Aceh yang dikenal taat beragama, di masa lampau bahkan pengibar panji perang sabil yang gagah perkasa, dan kini satu-satunya daerah yang menerapkan Syari'at Islam dalam kehidupan sehari-harinya, tiba-tiba diberi azab Tuhan yang begitu dahsyat dan tragis? Samakah rakyat Aceh dengan kaum Saba, Madyan, dan umat-umat terdahulu yang diazab Tuhan karena ingkar kepada Rasul, ajaran, dan Tuhannya? penulis yakin tak akan satu orang pun, apalagi para mubaligh yang akan berpendapat demikian. Allah pun pasti maha adil, maha bijaksana, maha Rahman dan Rahim kepada umatnya. Dia tak akan pernah salah memberi siksa, sebagaimana Dia tak akan salah alamat melimpahkan pahala.

Rakyat Aceh pun tentu akan makin sedih dan terpukul. Betapa mereka harus menerima konstruksi ayat-ayat Alquran yang dialamatkan secara salah-tafsir kepadanya. Seakan mereka dimurkai dan kemudian diazab Tuhan. Mereka sungguh bukan kaum Saba, Madyan, kaum Nuh, kaum Hud, dan umat-umat terdahulu yang diazab Tuhan.

Lalu, di mana kekeliruan para mubaligh pembawa risalah Tuhan itu? Boleh jadi kekeliruannya terletak pada pemaknaan dan penatsiran ayat yang selain dogmatis dan sernpit, juga tak mempertautkan dengan realitas yang dihadapi secara cerdas dan akurat. Ayat yang terkait dalam satu konteks sejarah tertentu terlalu terburu-buru diterapkan untuk menjelaskan konteks sejarah lain dalam realitas yang berbeda dan bahkan kontradiktif. Ayatnya benar, tetapi pemaknaan; penafsiran, dan konstruksinya terhadap realitas tidak tepat. Kalau pun mau menjelaskan realitas dengan ayat-ayat bencana, tentu ruang konstruksinya harus dibuka lebar, sehingga tidak menghakimi satu realitas secara dogmatis dan hitam-putih dengan pisau tafsir yang terbatas dan ruang yang terbatas pula. Dj situlah terjadi falsifikasi tafsir. Kesalahan dalam menarik dan mengkonstruksi tafsir. ${ }^{10}$

\section{Musibah Alam: Akibat Perbuatan Manusia atau kehendak Tuhan?}

Penulis melihat, ketika beberapa musibah menimpa kita akhir-akhir ini, banyak kolomnis dan penceramah yang menukil-nukil surat As-Syûrâ ayat 30 tanpa penjelasan yang memadai. Realitas ini sangat berbahaya karena dapat menimbulkan mis-understanding seperti yang selama ini terjadi dalam pemahaman teologi Islam, khususnya yang berkenaan dengan Sifat Irâdah. Bagaimana pun, yang utama untuk diyakini oleh umat adalah bahwa Allah Swt tidak akan pernah berkehendak buruk kepada hamba-hamba-Nya. Ada banyak hal yang perlu diresapi ketika menghadapi kenyataan yang, dalam pandangan manusia yang terbatas adalah pahit. Pertama, tidak semua kejadian tersebut "pahit" dalam arti yang sesuai dengan pemahaman manusia. Seluruh manusia adalah milik Allah Swt, maka Dia berhak mengambilnya sewaktu-waktu, dengan berbagai jalan, baik itu bencana alam, tertabrak mobil, atau kejatuhan bom seperti yang sedang melanda masyarakat Irak. Semua itu adalah bentuk "pemanggilan" Allah Swt terhadap manusia. Bentuk pemanggilan yang bermacam-macam itu seharusnya sudah tidak penting bagi manusia, atau bagi-Nya. Bentuk-bentuk itu

${ }^{10}$ Haedar Nashir. 2005. Logika Aceh. http: //www.kompa.com/kompas-cetak/0501/14/ oponil 1492211/htm/11:29:00 GMT. Accessed, 17 Januari 2005. 
hanyalah hal "profan" yang, sudah barang tentu, rasional. Karena rumusannya adalah rasionalitas, maka segala macam manusia akan tunduk dalam hukum ini, yakni hukum alam. Walaupun segala bencana adalah rasional, namun Islam mensyariatkan kepada umatnya untuk ber-istirjâ', yaitu ketika mendapatkan musibah segera mengucapkan Inná Lillāhi wa Innâ llayhi Râji'ûn, yang berarti "Sesungguhnya kami adalah milik Allah Swt, dan hanya kepadaNya-lah kami kembali". Ucapan ini memang terlihat sederhana, namun ia memiliki makna teologis yang sangat mendalam, yakni mengingatkan manusia untuk senantiasa ber-Tauhid, ber-Qadhâ dan ber-Qadar."

Yang kedua, mengenai hukum aiam. Hukum alam adalah hukum yang ditetapkan (Qadhâ) oleh Allah SWT yang berkenaan dengan rumusan-rumusan dan teori-teori tentang alam. Hukum ini akan berlaku bagi siapa saja yang melanggarnya, baik itu kaum theis maupun atheis, orang saleh maupun durhaka, dan sebagainya. Dari hukum inilah seluruh aktivitas alam semesta berlangsung, dari yang terkecil-seperti adanya hukum bahwa air akan mendidih pada suhu 100 derajat celcius, siapapun yang memasaknya, baik atheis maupun theis-atau bahkan yang lebih kecil dari kasus itu, hingga yang peristiwa-peristiwa terbesar yang ada di jagad dunia. Itu semua merupakan Qadhâ-secara etimologis berarti hukum atau ketetapan. Dan ketika manusia telah melewati proses Qadhâ itu maka dia akan mengalami apa yang sering disebut sebagai Qadar atau Takdir. Dengan demikian, Takdir adalah suatu hasil proses dari hukum dan ketetapan Allah Swt-yang berupa hukum alam-dengan realitas kehidupan yang dijalani manusia. ${ }^{12}$

Hukum alam yang diberlakukan oleh Allah Swt tersebut berbeda dengan hukum Aqidah atau Syariat yang diturunkan oleh-
Nya. Hukum alam yang dihadapi sekarang adalah hukum yang hanya berlaku di dunia fana. Sedangkan hukum Aqidah \& Syariat berlaku di dunia dan (untuk kepentingan) akhirat sekaligus. Dengan demikian, dalam hal tertentu, hukum alam tersebut sama sekali tak memiliki kaitan "erat" dengan hukum Aqidah \& Syariat. Artinya, hukum alam akan menerkam siapa saja yang melanggarnya, baik itu manusia-saleh, fasik $\&$ ateis-hewan dan lainnya. Namun demikian, perlu diperhatikan, bahwasanya korban keganasan hukum alam tak selamanya adalah pelaku dari pelanggaran atas hukum alam tersebut. Bahkan juga bisa dikatakan bahwa proses yang terjadi dalam hukum tak mesti melibatkan manusia. Sebagai contoh adalah peristiwaperistiwa yang terjadi di luar angkasa. Demikian pula sebalikya, hukum Aqidah \& Syariat tak berkaitan langsung dengan kedatangan hukuman alam. Lalu, bagaimana dengan adanya hukum alam yang terjadi pada umat-umat terdahulu, sebagaimana dikisahkan di dalam alQur'an? Allah Swt, dalam memberikan kenikmatan, ujian, cobaan atau siksaan tidaklah melampaui nalar kemanusiaan. Artinya, jika Allah Swt menyatakan telah memberikan hukuman melalui hukumhukum alam, maka hukuman alam itu terproses melalui pelanggaran hukum Aqidah \& Syariah yang-tanpa pernah disadari-berakibat (juga) kepada pelanggaran atas hukum alam. Dari sinilah hukuman berlaku, dan secara hakekat ia bukanlah hukuman atas kedurhakaan kepada-Nya, karena semua hukuman (Jazâ', Hisâb) atas kedurhakaan kepadaNya telah di-setting pada Hari Pembalasan (Yawmul-Jazâ) atau Hari Penghitungan

"M. Luthfi Thomafi, Loc. Cit. 12 lbid. 
(Yawmul-Hisâb) dimana masing-masing manusia akan menghadapinya. ${ }^{13}$

\section{Menyikapi Musibah Alam}

Kebingungan masyarakat dalam menyikapi peristiwa Aceh dan simpang siurnya pernyataan antara ujian dan cobaan ataukah murka dan azab, menurut penulis, disebabkan cara pandang yang menempatkan ujian dan cobaan serta murka dan azab secara inheren pada satu peristiwa. Para pencinta lingkungan hidup misalnya, mengatakan bahwa bencana alam itu, seperti halnya dengan bencana alam lainnya, sebagai pertanda kemarahan alam atas ulah manusia yang kurang menghormati lingkungan, yang serakah, dan menguras alam tanpa batas.

Apa pun pesan yang disampaikan di balik tragedi tersebut, satu hal yang dapat dikatakan, itu semua sebagai blessing in disguise, hikmah yang tersembunyi. Bahwasanya, tragedi-tragedi itu menggugat manusia untuk melihat lebih cermat, lebih tajam dan lebih dalam lagi seputar keharmonisan antara manusia, bumi dan alam sekitarnya. Ada semacam ketidakberesan yang amat serius antara manusia dan alam, sehingga sangat diperlukan keterlibatan dan tanggung jawab manusia untuk mengharmonisasikannya kembali.

Bukankah manusia adalah makhluk yang paling sempurna dan memiliki derajat jauh lebih tinggi daripada makhluk ciptaan lainnya? Satu hal lain yang tidak bisa disangkal bahwa tragedi berupa bencana alam selama ini banyak yang merupakan akibat langsung dari hasil pelecehan manusia terhadap lingkungan (ecological harassment) berikut kekerasan lingkungan (ecological violence) yang terjadi pada masyarakat modern yang senantiasa mengagungkan teknologi yang dihasil- kannya. Lebih jauh, tindakan pemerkosaan manusia terhadap hak-hak alam selama ini, misalnya, bukan hanya menimbulkan bias berupa banjir dan tanah longsor, tetapi telah sampai pada situasi pemusnahan keanekaragaman sumber daya hayati maupun alami (ecocide) yang mengancam kelangsungan hidup manusia. ${ }^{14}$

Di sini diperlukan adanya refleksi spirjtual secara kritis dan kontekstual, yang berupaya menanggapi secara serius berbagai permasalahan lingkungan hidup dan segala sesuatu yang bertalian dengan itu, guna melahirkan aksi transformatif untuk melakukan emansipasi praktis. Dengan demikian, timbullah kesadaran untuk tidak merusak alam, yang dari dalamnya terlahir sebuah perspektif ke-llahian. Perspektif kellahian ini pada gilirannya tidak hanya mampu menggerakkan partisipasi sosialpelestarian lingkungan, tetapi terutama diperlukan untuk memberikan orientasi bagi sebuah transformasi yang lebih bersifat holistik dan landasan pilihan etik lingkungan serta memberi makna bagi upaya pencapaian kehidupan semesta yang lebih harmonis. Artinya, diperlukan hadirnya pemikiran-pemikiran spiritual-teologis yang lebih bersifat transformatif dan holistik, serta etika lingkungan yang lebih membumi yang bisa menjadi wadah bagi setiap wacana dan aksi-praksis pelestarian lingkungan. Untuk jtu, tampaknya manusia memerlukan pandangan yang lebih mendasar mengenai alam dan lingkungan hidup.

Dengan demikian, tepat bila kini segera diletakkan arah manakah .sebuah

${ }^{13}$ Ibid.

${ }_{14}$ Thomas Koten, 2005, Catatan Pasca Tsunami Aceh Orientasi Baru Etika Lingkungan. http/www.Suara Merdeka.com/ harian/0502/18/opi 03/htm/accessed, 18 Februari 2005. 
pemaknaan hidup spiritual dan teologis kita mengenai lingkungan dimulai, yaitu baik dari segi empirik dan kontekstual maupun dari segi sejarah pemikiran keagamaan kita yang ada selama ini mengenai alam dan/ atau lingkungan hidup.

Lain lagi dengan masyarakat muslim di sekitar Aceh dan Sumatera Utara dalam menyikapi musibah tsunami dan gempa bumi di Aceh, mereka mengadakan acara tahlil akbar mengenang empat puluh hari musibah tersebut. ${ }^{15}$ Menurut Tarigan, pesan Tahlil Akbar ini bukan sekadar ingin mendoakan korban tsunami saja. Lebih dari itu acara ini dapat dilihat dari berbagai sisi, seperti aspek teologi-filosofis dan phsycososiologis. ${ }^{16}$ Untuk yang pertama, gempa dan tsunami menyadarkan semua orang akan kemahakuasaan dan kebesaran Allah SWT. Dengan peristiwa ini manusia sadar bahwa sesungguhnya tidak ada yang abadi di muka bumi. Harta benda yang dicari dengan susah payah dapat hilang dalam waktu yang sangat cepat jika Allah menghendaki. Anak, istri, suami dan orang tua, juga dapat hilang tanpa bisa bertemu kembali karena digulung badai tsunami. Tidak ada satu pun yang dapat mencegah jika Allah menghendaki.

Secara filosofis, musibah gempa dan tsunami juga mengingatkan manusia bahwa kemajuan ilmu pengetahuan dan teknologi tidaklah harus digunakan untuk menguasai alam, sesuatu yang tidak mungkin dilakukan, melainkan harus digunakan sebagai sarana mendekatkan diri kepada Allah dan diorientasikan untuk kesejahteraan manusia.

Seringkali kemajuan Iptek yang semakin canggih membuat manusia memperoleh kemudahan-kemudahan di dalam hidupnya. Bahkan, segala sesuatunya dapat diprediksi dengan mudah sehingga manusia mampu memberikan antisipasi-antisipasi terhadap segala kemungkinan masa depan. Sayangnya perkembangan ilmu yang menggunakan paradigma positivism tersebut, membuat Tuhan menjadi absen dalam kehidupan manusia dan tidak dilibatkan dalam kalkulași-kalkulasi ilmiah. Akhirnya, manusia merasa berkuasa dengan ilmunya dan ingin pula menguasai apa saja dengan ilmunya.

Dengan peristiwa ini seharusnya manusia menjadi sadar, bahwa ilmu pengetahuan haruslah diorientasikan untuk menambah keimanannya. Setiap kali terjadi penemuan-penemuan ilmiah bagaimanapun hebatnya, haruslah membuat manusia semakin sadar akan kemahakuasaan Allah. Selanjutnya kemajuan Iptek haruslah dalam rangka menjaga keseimbangan antara makro kosmos (alam raya) dengan mikro kosmos (manusia). Jika tidak terjadi keseimbangan antara alam dan manusia yang pada dasarnya diciptakan secara harmonis, dapat berubah menjadi chaos (kacau) yang pada gilirannya dapat menyengsarakan manusia itu sendiri. Sesuatu yang tidak boleh diabaikan, eksploitasi terhadap alam tetap saja tidak dapat dibenarkan dengan alasan apapun. Sebaliknya, dengan kemajuan Iptek sumber daya alam akan dapat dimanfaatkan seluasluasnya untuk kemaslahatan manusia. ${ }^{17}$

Secara phsyico-sosiologis acara tahlil akbar tersebut sangat penting dalam

15 "Undangan Tahli Akbar Mengenang Empat puluh hari Musibah Tsunami", Dalam Harian Waspada, 26 Januari 2005. Medan.

${ }^{16}$ Azhari Akmal Tarigan. 2005. $40 \mathrm{Hari}$ Musibah Tsunami dan Tahlil Akbar, http:// www.pesantrenvirtual.com/artikel. php? id=991/15:53:13 GMT, accessed, 22 Februari 2005.

17 lbid. 
memberikan kekuatan baru terhadap korban tsunami. Mungkin bagi yang telah meninggal dunia, kita hanya mampu berdoa semoga Allah menerima arwah mereka dan menempatkannya di tempat yang layak di sisinya.

Namun bagi korban yang selamat, masalahnya sangat berat. Dalam waktu satu tahun mereka dapat membangun rumahnya kembali. Mereka juga dapat kembali bekerja untuk memenuhi kehidupannya. Namun trauma yang dialami, duka dan kesedihan yang masih membekas karena kehilangan keluarga yang mereka cintai, tentu tidak dapat diselesaikan dalam hitungan bulan atau tahun. Inilah masalah terberat yang dihadapi para korban dari sekadar merekonstruksi bangunan fisik.

Untuk itu acara tahlil dan sejenisnya dapat memberikan dua nilai penting. Dengan acara ini, dapat memberi kesan bahwa korban tsunami tidak sendirian dalam menghadapinya. Bukan hanya mereka yang bersedih dan menangis, tetapi kita juga merasakan hal yang sama. Dengan acara tersebut dapat ditunjukkan, bahwa kita adalah saudara-saudara mereka dalam kesedihan. Kedua, dengan acara tahlil ini, tidak ada pendekatan yang paling efektif untuk mengobati trauma dan kesedihan korban kecuali dengan pendekatan agama. Di sinilah peran agama untuk memberikan penguatan phsyicologis korban menjadi sangat penting. ${ }^{18}$

Penulis sendiri berpandangan, pada dasarnya, peristiwa atau bencana apa pun, betapa pun dahsyatnya, pada dirinya sendiri adalah netral. la baru dapat disebut ujian, cobaan, murka, atau azab ketika dikaitkan dengan perbuatan manusia. Tidak ada satu pun yang berhak menghakimi seseorang atau sekelompok masyarakat yang ditimpa suatu peristiwa sebagai murka atau azab Tuhan, kecuali dirinya sendiri. Merekalah yang paling mengetahui apa yang mereka lakukan. Merekalah yang paling bisa memaknai apa yang sedang menimpa mereka. ${ }^{19}$

Selain itu ketika terjadi peristiwa seperti gempa dan tsunami di Aceh, tidak bisa digeneralisasi bahwa secara keseluruhan itu adalah ujian dan cobaan atau murka dan azab. Peristiwa bersifat individual, bukan kolektif. Satu peristiwa yang sama bisa menjadi semacam ujian atau cobaan pada satu pihak, namun di pihak lain, ia merupakan azab dan murka Tuhan. Sekali lagi, hanya mereka yang ditimpa bencana alam itulah yang lebih tahu dan lebih dapat memaknai secara tepat apa yang telah terjadi. ${ }^{20}$

\section{Penutup}

Berangkat dari paparan tersebut, masyarakat di kawasan lain yang tidak mendapat musibah gempa dan tsunami. banjir, atau apapun namanya, jangan terpaku pada perdebatan teologis yang menghakimi.

Kekeliruan tafsir dan mengkonstruksikan tafsir itu dalam realitas, juga selain akan memukul batin mereka yang terkena bencana, pada saat yang sama bisa membuat lalai atau bahkan pongah mereka yang tak terkena bencana. Kalau mereka yang terkena bencana digambarkan menerima azab karena ingkar dan tak bersyukur, maka orang-orang yang berada di daerah aman akan merasa sebagai umat yang beriman, bertaqwa, bersyukur, dan dikasihi Tuhan.

\section{8 lbid.}

${ }^{19}$ Rahmani TY, 2005. "Meluruskan Teologi Tsunami". Dalam Jawa Pos, 26 Januari 2005. Surabaya.

${ }^{20}$ ibid. 
Jangan bebani rakyat Aceh dengan logika-logika yang salah-kaprah dan menyesatkan. Kini, ketika musibah menimpa tak pilih kasih, yang diperlukan ialah sikap empati yang tulus dari seluruh anak negeri. Hormatilah martabat rakyat Aceh. Jika tak mampu membantu meringankan beban dan melakukan pemulihan atas bencana rakyat di Serambi Mekah itu, setidak-tidaknya hindari logikalogika yang menghukum secara salah kaprah.

Tetapi, belajar dari peristiwa buruk itu, marilah kita terus mengulurkan tangan, membantu mereka. Satu hal lain yang patut menjadi renungan ternyata kehancuran manusia tidak melulu karena perbuatan manusia sendiri. Perbuatan Tuhan, sebagaimana peristiwa gempa dan tsunami, telah membuktikan hal tersebut.

Tulisan ini dibuat tanpa pretensi memberi solusi tuntas dan memuaskan terhadap pertanyaan teologis yang usianya setua peradaban manusia. Kalaupun ada kontribusinya, hal itu terletak pada upayanya memaparkan-atau, bahkan, hanya meringkaskan-solusi yang pernah ditawarkan terhadap persoalan ini. Persoalan teologis, pendekatan yang dipakai bersifat nyaris sepenuhnya filosofis. Jika setelah membaca tulisan ini orang paham bahwa, persoalannya sama sekali tidak sederhana-oleh karena itu, kita tidak gegabah menarik kesimpulan atas persoalan terdalam hakikat kehidupan manusia di bumi ini, maka penulis menganggap tujuan penulisan ini sudah tercapai.

Semoga ini akan menjadi pelajaran bagi kita bahwa pada dasarnya manusia hanyalah setitik debu yang tidak memiliki kemampuan apa-apa di alam jagat ini. Manusia lemah, lalu mengapa banyak di antara manusia yang menjadi arogan?

\section{Daftar Pustaka}

"Undangan Tahlil Akbar Mengenang Empat puluh hari Musibah tsunami', Dalam Harian Waspada, 26 Januari 2005. Medan.

Koten, Thomas. 2005. "Catatan Pasca Tsunami Aceh Orientasi Baru Etika Lingkungan"From http://www. Suara merdeka. Com/harian/0502/18/opi03/ htm/accessed, 18 Februari 2005.

Nashir, Haedar. 2005. "Logika Aceh"From http:/www kompas. Com/kompascetak /0501/14/opini/1492211. htm/ 11:29:00 GMT. Accessed, 17 Januari 2005.

Nasution, Harun. 1986. Teologi Islam. Jakarta: UI Press.

1987. Muhammad Abdul dan Teologi Rasional Mu'tazilah. Jakarta: Ul Press.

1991. Filsafat Agama, Jakarta: PT. Bulan Bintang.

Novriantoni, 2005. "Tuhan Pasca Tsunami" From http://www kompas. Com/ kompas - Cetak/0501/14/Opini/ 14922 11.htm/11: 29: 00 GMT. Accessed, 17 Januari 2005.

Rahmani TY. 2005. “Meluruskan Teologi Tsunami". Dalam Jawa Pos, 26 Januari 2005. Surabaya.

Syafiie, Imam, 2000. Konsep IImu Pengetahuan Dalam Al Qur'an. Yogyakarta: UII Press.

Tarigan, Azhari Akmal. 2005. "40 Hari Musibah Tsunami Dan Tahlil Akbat" 
Menyikapi Musibah Alam: Suatu Upaya Meluruskan...; Rahmani Timorita Yulianti Form http:// www.pesantrenvirtual.com/artikel. www.pesantrenvirtual.com/artikel. Php? Id = 991/15: 53: 13 GMT. AcPhp? Id = 991/15: 53: 13 GMT. Accessed, 22 Februari 2005.

Thomafi, M. Luthfi. 2005. "Musibah Alam Dalam Perspektif Teologi Islam". Form http://

Yun. 2004. "Gempa itu TerbesarSepanjang Sejarah". Dalam Kompas, 27 Desember 2004. Jakarta. 